\title{
The Application of Geospatial Intelligence in National Security for Sustainable Development to combat Terrorism Insurgence in Nigeria
}

\author{
Emenari Udochukwu.S, Uwaezuoke Ifeanyichukwu Christian, \\ Adewale Adebayo \\ Department of Surveying and Geoinformatics \\ Waziri Umaru Federal Polytechnic \\ Birnin Kebbi, Kebbi State, Nigeria
}

\begin{abstract}
The development of a nation stands on a tripod which is food, shelter and security; security which is a major factor plays a vital role and should not be jeopardized, when it is jeopardized there is deterioration, depression, downcast and so on, in the economic and welfare of the citizenry. It is therefore important that a wise nation, allot more attention to it. This research work looked into the concept of security, how geospatial intelligence has helped nations of the world to develop and to sustain the development, the history of terrorism in Nigeria which is a major treat to security, it also looked at how geospatial intelligent has assisted and can assist in taking care of cases of terrorism. The applications of geospatial techniques were then discussed and challenges which Nigerian government is facing were posed. The work was concluded by encouraging the government of Nigeria to employ the methods used by developed nations and more so tackle the challenges of funds, Inadequate satellite imagery, Lack of dedicated security satellite to curb terrorism, Inadequate trained personnel, Lack of Integration of all database within the country, with these challenges the researchers believes that the issue of security in Nigeria if not been a forgotten issue, will be drastically reduced.
\end{abstract}

Keywords: Security, Terrorism, Sustainable, development, Geospatial, Intelligence

\section{Introduction}

The word geospatial isinterchangely use as graphic information or Geographic Information System, it has been define by many scholars and one of such definition is that it is a computer system that records, stores, and analyzes information about the features that make up the earth's surface. A GIS can generate two- or threedimensional images of an area, showing such natural features as hills and rivers with artificial features such as roads and power lines. Scientists use GIS images as models, making precise measurements, gathering data, and testing ideas with the help of the computer.Geospatial technology has tremendously revolutionized the way we do things in ourlives and it's still doing so in today's world.

Taking this explanation into bear,it may be important to ask the question, what is Geospatial intelligence? It is an intelligent discipline and tradecraft that has evolve from the integration of imagery, imagery intelligence, geospatial information and on a broader scale encompasses all aspect of imagery (including capabilities formerly referred to as Advanced Geospatial Intelligence and imagery) and geospatial information and services; formerly referred to as mapping, charting, and geodesy. It includes but not limited to, data ranging from the ultraviolet through the microwave portions of the electromagnetic spectrum, as well as information derived from the analysis of literal imagery, geospatial data; and information technically derived from processing, exploitation, literal and non-literal analysis of spectral, spatial, temporal, radiometric, phase history, polarimetric data, fused products (that is product created out of two or more data sources), and the ancillary data needed for data processing and exploitation, and signature information (to include development, validation, simulation, data archival, and dissemination ). These types of data can be collected on stationary and moving targets by electro-optical related sensor programs (both active and passive) and non-technical means (to include geospatial information acquired by personnel in the field) National Geospatial Intelligence United State, Agency, 2006 and Wikipedia, 2012.

Considering these enormous innate resources of Geospatial intelligence it is only reasonable for any dutiful government to take advantage of such, in cubing the excesses of any group that stand as a threat to national security.

\section{The Concept Of Security}

Security stands as one of the basic necessities to human existing; the idea of security in this research is tailored at the guarding of life and property and not in the context of food, water and shelter for tomorrow. 


\section{National Security And Sustainable Development}

National security is the requirement to maintain the survival of the state through the use of economic power, diplomacy, power projection and political power. It is a word that was developed or coined by the United Stated after world war two and initially focuses on military might but now encompasses a broad range of facets, all of which impinge on the non military or economic security of the nation and the values espouse by the national society.The United State of America define National Security as the ability of the National institutions to prevent adversaries from using force to harm Americans or their national interests and the confidence of Americans in this capability(Sam C. Sarkesain et al., 2008).Considering that US is the "police" of the world, if an attempt is made to rephrase the definition earlier mentionedto suit the Nigeria situation, it therefore means that it is the ability of the national institutions to prevent adversaries from using force to harm Nigerians or their national interests and the confidence of Nigerians in this capability.

Further explanation as put forward by (Imobigbe, cited in Anyadike 2013) refers to it as the defense and survival of the state. From Dyke, 1966, national security no doubt embodies the sovereignty of the state, the inviolability of its territorial boundaries, and the right of individuals and collective self-defense against internal and external threats. Although this description stand yet for there to be true national security for sequential national development, the citizen need to put resources together gear at ensuring that everybody is carry along in termsof human rights, justice, equal economic opportunity and spread of infrastructural developments for all and the independent of a nation sovereignty in relation to its foreign policy.

Also, the Gro Harlem Brundtland Commission define sustainable development as the ability to make development sustainable - to ensure that it meets the needs of the present without compromising the ability of the future generations to meet their own needs. This is surely the standard definition when judge by its widespread use and frequency of citation (Robert W. Kateet al., 2005).(Oluwaseun B, 2012)refer to it as a partner of resources use that aims to meet human needs while keeping the environment so that these needs can be met only in the present but also for generations to come. Further description by the UNESCO puts it as the will to follow a rational to economic administration and the creation of economic policies, to manage public matters efficiently and predictably, to show respect for future generations by integrating a concern for environmental protection in decision making and progressively evolving towards democracy the-full participation of all concerned actors, while taking into account specific local circumstances.

Linking this two description together the Brundtland Commissionin 1992,explains that sustainable development draws strength from its integration of multiple factors affecting the society, and political substances from its indeterminate nature, which allows people of many different backgrounds and perspectives to agree that sustainable development, should be embraced as a world goal. This give us the understanding that where there is a threat to national security, the chance of sustainable development fizzle out considering the huge distraction and incoherence it breeds in terms of integration and all round developmental activities to the society.

\section{Historical Trace Of Terrorism In Nigeria}

Apart from the religious/inter ethnic crises witnessed in the country, Nigeria can be said to be free from any form of insurgence such as terrorism, ritualism, violent crime and kidnapping within the era of 1960's, not until in late 90's when the issue of insecurity started and further culminating in today's epidemic proportion. In Nigeria, terrorism was tailored to Boko Haram insurgency and kidnapping which started from North East and South-South Nigeria respectively before it got to other parts of the nation.

In term of Boko Haram Sect, people have diverse views concerning its origin, some analysts regarded it as an outgrowth of the Maitatsine riots of 1980s and religious/ethnic tensions that followed in late 1990 (Johnson, 2011), while some thought, it has its roots in the Sahaba group, which Mohammed Yusuf came to lead in the late 1990s before reorienting the group as Boko Haram. Mohammed Yusuf was a favorite's student of a prominent Nigerian Islamic scholar Sheikh Jafar Mahmud Adam. It has been reported that the two fell out over Yusuf's extremist positions, with Boko Haram, then known by some as the Yusufiyya sect, moving from Kano State to Yusuf's hometown of Maiduguri, in Borno State, in 2004. When Jafar was murdered in 2007, some Kano clerics have alleged that Yusuf loyalists, who reportedly interrupted Jafar's sermons after their falling out, were behind the murder (Dearn, 2011). Boko Haram became more popular in 2009, due to its participation in sectarian violence which occurred then in Northern Nigeria which lead to the death of Mohammed Yusuf who was said to have been killed by Nigerian Police Force. After his death, Abubakar Shekau became new Boko Haram leader and still holds that position today. Other prominent members of the group include Abdul Qaqa and Abu Zaid, both spokesperson of the group.

Another major security problem shaking Nigeria Nation is kidnapping and violent crime meted out to individuals, foreign oil and construction workers as well as the series of attacks on the oil facilities by militants in the Niger-delta region in the South-Southern part of Nigeria. A group known as the Movement for the Emancipation of the Niger Delta (MEND) has claimed responsibility for most of these attacks. This started on 
September $16^{\mathrm{TH}}$, 2005 when another group named as the Ijaw youth council (IYC) threatened to attack British nationals and facilities in the Niger-delta if the British police failed to released a former governor of Bayelsa State who was arrested in London, for money laundering offences. Again, On September $20^{\mathrm{TH}}, 2005$, a leader of another group named Alhaji AsariDokubo, leader of the Niger-Delta People's Volunteer Force (NDPVF) was arrested by the Nigerian government in connection with the rising tension in the Niger-delta

On September $22^{\mathrm{ND}}, 2005$, armed militants of the NDPVF seized an oil pumping station in PortHarcourt, a facility that produces about 7,000 barrels of oil per day. This was done in protest against the arrest of the NDPVF leader.

January $11^{\mathrm{TH}}, 2006$, the first reported case of abduction of expatriates took place when 4 foreign oil workers working on the AE fields of Shell petroleum were kidnapped by militants in Port Harcourt. This resulted in a further cut-back of 120,000 barrels per day in crude oil production (Adelakun, 2007). Due to threat not only to Nigeria's oil production, but country fragile democratic transition, Federal government now sought to end the conflict through an act of amnesty issued on $25^{\text {th }}$ April, 2009, which yielded partial result since the attack on oil installation and kidnapping not to only foreigners but the citizen of the country still continues (Boer, 2012). Kidnapping and other violent crimes spread out from South-South to South East to South West and to the entire Nigeria. Recently, issues of ritualism, baby making homes are being reported in South East and South West Nigeria which is still a threat to the nation nascent democracy.

The US Department of states reported that within fifteen (15) countries surveyed in 2011 for terrorism and kidnapping, Nigeria ranked fifth (5) and fifteen (15) respectively, with only 17 kidnapping cases reported then, though the report was underestimated (Fatowora, 2012).

The rate of terrorism in Nigeria is still increasing day by day with recent bombing of Nyanya outskirt of Abuja, rumor of bombing of Ibadan- Lagos Express road as well as abduction of Chibok School girls in Maiduguri by the terrorist which still remain our own missing Malaysian plane, these lead to heighten tension in entire Nigeria. Nobody knows where it will be tomorrow couple with government insensitivity in tackling the menace which will impinge the process ofsustainable development in Nigeria

\section{The Geospatial Intelligence Participation}

First used by the Canadian government in 1960 s to analyze data collected by the Canada land inventory, other governments and university laboratories soon built similar systems. Though it was not widely used until the late 1970s, when technological improvements and lower costs made computers widely available. GIS sales boomed during the 1980s, as governments and businesses found more uses for the systems. A number of companies began producing new GIS software to program computer systems to increase their functions. By the early 1990 s, about 100,000 GIS systems were in operation.

As this transformation was on going, the intelligence community have been using Geospatial Intelligence although not called by that name since June, 1803 when Thomas Jefferson the then President of United State of America commissioned Captain Meriwether Lewis to explore the new territory gained by Louisiana purchase which lead to an early combination of mapping and intelligence reporting to meet the needs of the new nation's leaders. Between 1803 and 1917 series of development were made in the art of using photographic in gathering intelligence data for warfare such as the use of balloon with a fitted cameral to carryout aerial photographic as was the case in 1898 when it was used in determining the best route to bring US troop to San Juan Hill during the Spanish American War. The World War II, Cold War Era and Vietnam War witnessed an increase in the use of geospatial intelligence as a result of technological advancement. In the case of World War II, it was use in combat operations, strategic planning, and specifically it assist Allies in knowing the wonder weapons of German which gave the scientific community an insight into the next generation of airborne firepower.

During the Cold War Era, the need to apply technology in gathering information in areas know as the strong hold of the Soviet Union became paramount and as a result, satellite and new reconnaissance aircraft were used in the analysis of aerial photographs capture during World War II in Eastern Europe to give policymakers in the US authoritative knowledge about Russian capabilities.

Before the US and Allied forces invaded Vietnam, a comprehensive aerial photograph was carried out and analyzed using the U-2 aircraft and SR-71 Black Bird aircraft photograph so that exact coordinates of newly found targets can be capture and action taken. In addition to these, the use of GIS in the defeat of Iraq by the USA led Allied force in 1991 Gulf War has greatly been acknowledged.

While these can be said to be a massive use of geospatial intelligences in the USA, other countries like Afghanistan and Russia have also gained from the knowledge of using geospatial intelligence to solve the task of dealing with terrorism.

The conflict in Afghanistan has throw up many challenges both for the forces which operate in the country and those planning military operations. Geospatial systems have played a role in combating insurgency within urban conflict in Afghanistan war and are also been used in the efforts to rebuild the country. Through 
the help of France, National Atlantic Treaty Organization (NATO) and other European nations, many remote areas in Afghanistan and Asia which lack geospatial data where covered when troops were deployed for operations. In addition, a flood hazard map was produce by NATO and handed over to the Afghan authority to ensure flood defense measure are positioned effectively and to see that construction are not carry out in these areas prone to flood.

However, in more recent times, Russia deploy this expertise in the last Sochi Olympic games when people around the world were enjoying the games geospatial analysts were imaging the events via constellation of commercial high- resolution satellite and adding layers of social media data from web intelligence company. Also, cities were the events are played were fully mapped before the event and secure with the use of field security men guided by the knowledge obtained from the geospatial intelligence.

This great nation Nigeria can borrow a leaf from these nations and built on already existing technology to combat this onerous scourge of a newly found means of destabilize the country.

\section{Application Of Geospatial Intelligence In Security}

Terrorism is a very sensitive issue and must be taken with caution, the application of remote sensing and Geographic Information System is one of the most important methods of combating it in this present generation. Every material or object has it emissivity, which is a measure of material to both radiate and absorb energy, material with a high emissivity absorb and radiate large proportions of incident and kinetic energy respectively and vice versa, meaning that two objects with same kinetic temperature and different emissivity will have a different radiant temperature. Also the objects on the image obtained from satellite images have digital number and radiometric resolution which describe its ability to discriminate very slight differences in energy, the finer the radiometric resolution of a sensor, the more sensitive it is to detecting small difference in the reflected or emitted energy. It can be noted thence that from a processed satellite image tree can be identified as tree, water as water etc. Using this information the position of any group of people such as terrorist camps can be easily identified if the military camp identified witha particular reflectance as a group of people, comparing this information with that on the other part of the image, by creating training site of the military zone.

For any terrorist to survive, water is one the major sources of their livelihood, food cloths medication. Etc. can be obtained by invading a nearby community, but water cannot be easily conveyed, as such terrorist mainly settle where there is easy water supply, the source of the water supply can be easily traced using the satellite image, and the waterchannel will lead the military to the camp of the terrorist.

More so, a series of imageries within the suspected area per time of say every hour can be used to monitor the movement of terrorist to and fro their camp to other locations around them. The images where there are no reflectance of human will be compared with that which consist of human, with several images, the direction of movement can be predicted and they can beambushed.

Incorporating GIS into remote sensing information, distances for military camp to the terrorist camp can be determined, relationship between objects in an around the camp, escape routes, possible equipment/ materials used by the group can be obtained thorough analysis of the different spectral characteristics of each object.

Furthermore, puttingGlobal Positioning System (GPS) chips on a person can help to detect the location of the individualsuch that,the person position can be traced anywhere he/she goes. For example in South America, where a lot of terrorism ishappening some wealth individuals use it, such that when they are kidnapped they can be traced. The same system can be employed inNigeria especiallyin South-South and SouthEast geopolitical zones where most rich men have been forced to move out of their state for fear of been kidnapped.

With these in place and properly harnessed, the country can defend its territory sovereignty in term of insecurity as well as boast the confidence of the investors and Nigeria, thus leading to sustainable development.

\section{Challenges}

\section{Inadequate imageries:}

Different satellite imageries give different information for different purposes an example is Nigeria Sat 1 which is basically meant for communication. There are several satellite like Geoeye-1 $(0.41 \mathrm{~m})$, Worldview 1 and $2(0.46 \mathrm{~m})$ Pleiades $-1 \mathrm{~A}(0.5 \mathrm{~m})$, Quickbird $(0.61 \mathrm{~m})$,Iknons $(0.82 \mathrm{~m})$, Spot-6 (1.5m), Spot-5 (2.5/5m), Rapideye $(5 \mathrm{~m})$, Aster $(15 \mathrm{~m})$ and Landsat $-7+$ ETM $(30 \mathrm{~m})$, each of these satellite provides imageries corresponding to its ability, as such for security purpose an image with higher accuracy is expected to be used. Nigeria as one of the countries which make available satellite images cannot boast of any security images, whose image resolution are in the range of $0.41-.82 \mathrm{~m}$ to aid in combating terrorism. 


\section{Lack of dedicated security satellite to curb terrorism}

Nigeria as of today has about five satellites orbiting the earth which has application mainly on politics (Election monitoring), Natural disaster monitoring, agricultural support, real time weather forecasting, monitoring of ecological health of the country.None of the satellites were tailored towards solving security problemsmilitating the country by way of giving real-time information. This defect was due to non high spatial resolution required by military/spy satellite dedicated for security purposes which Nigeria satellites did not meet up with.

US Department of Defense developed Navigation Satellite Timing and Ranging (NAVSTAR) which became fully operational in December 1993 to tackle the issue of security followed by their counterpart Russia Aerospace Defense Force that developed Global Navigation Satellite System (GLONASS) which was completed in 1995. Apart from these countries, others have launched their own satellite dedicated to security such as Japan, Germany, and China to mention but few. Recently, Indian lunched its first defense Satellite GSAT-7 on July 1, 2013 which is dedicated solely for military use. The Indians were prompted in developing their own military Satellite because of denial of information from US when India government needed the GPS data to tackle its own insecurity problems. Nigeria government is not making any effort to develop its own military Satellite thus making them to depend entirely on foreign help. The big question is, when will this dependency end? Since this act ofinsecurity will also expose the country to foreigners, thus it is high time Nigeria developed its own dedicated Military satellite.

\section{Lack of Integration of all Database within the country}

Adatabasecan be define as an organize collection of data or any collection of data organized for storage in a computer memory and designed for easy access by authorize users. With this basic explanation of what a database stand for, it is pertinent to observe that in Nigeria different organizations like Federal Road Safety Corp (FRSC), National Population Commission (NCP), National Identity Management System (NIMS) and the Nigeria Police Force (NPF) among many others like the hospitals and schools have at some point collected personal data from the citizens but the government has fail to incorporate all these data gathered from various establishment into one to form a comprehensive database. These institutions can through an establishment of a centralize system at the federal level like the National System for Geospatial Intelligence as seen in the USAbring together these data to curb the challenges of terrorism. A case in point is the recent Nyanya motor park bombing that took place in Abuja at the federal capital territory (FCT) where more than seventy (70) people were killed (BBC online, 2 May, 2014 ), among the dead is an alleged BoKo Haram member who could not be identified. But where there is a database issues with identification can easily be resolve.

\section{Inadequate FUND}

Fund is one of the necessities for any sector in an economy to excel. The security sector over the year has witnessed an increase in budgetary allocation which many commentators said have not translated to improvement in security. These could be as a result of corruption among many other complicating issues bedeviling the country. Also, most of the funds available are not properly channel at intelligence gathering but rather on ground trooping which may not yield the desired result.According toan investigation done buy the TELL Magazine where barracks across the country were visited, it was revealed that each soldier on a 24 hours special duty against the BoKoHaram sect is paid $\$ 500$ a day as an allowance, making it a total of $\$ 3500$ weekly which are paid at the end of every week (Tell Magazine, cited in Anyadike2013). One can only imagine what that amount can do in motivating the security men who on a daily basis put their life on the line to secure the country yet there is an increase in budgetary allocation year in year out. To resolve this quagmire the President (Goodluck Jonathan)should match his words with action for it is not enough after each attack by terrorist to assure the Nation that the security forces are on top of the situation yet kidnapping, explosion of Bombs and other vices are still increasing.

\section{Inadequate trained personnel}

According to available report, the total strength of the Nigeria security workforces (Police, Army,Navy and Air force) are 534,000 with the Nigeria police having 371,000, 130,000 for the Army, 15,000 and 18,000 for the Air force and Navyrespectively (Babagida cited in Adebakin, 2012 ). Ifthis isplace side by side with the Nigeria population and using the ratio of United Nation on the number of security personnel to a citizen as a benchmark, it will be obvious that there is a great need to increase the number, yet, how many of these available personnel are well trained to physically and intelligently meet up with the security dynamics of the $21^{\text {st }}$ century to checkmate the excesses of the security perplexity facing this bless nation.In the words of Colonel Neil Thompson (retired) a distinguished Geospatial Intelligence career officer in Canadian forces, in one of his interview, on the rapid change in the battle field as it effects the application of geospatial intelligence, he said that the new generation of geospatial specialists must be highly trained, to clearly understand the requirements 
and be accurate in service delivery. This goes to show that training of security officer on the state of the art means on how to combat terrorism cannot be overemphasis. Therefore, with the recent high level of security collapse it is believe that the government will put words to action in the training and retraining of the security forces to manage the onerous task of policing the nation.

\section{Conclusion}

From books and article reviewed it is obvious that the application of geospatial intelligence in managing the challenges that come with terrorism in this country is minute considering the free hand by which this menace is been spreading from one state to another without enough intelligence and pragmatic approach aim at solving it. It is hopeful, that the government will build necessary relationship for exchange of ideas between Nigeria and other nations who has edge over us in resolving and mitigating the issue, and by extension with the application of the following recommendations there is bound to be a change if properly implemented these can lead the nation to the level of a sustainable development.

\section{Recommendations}

- The government should train all the security personnel starting from Paramilitary to military in area of counter terrorism, diffusion of bomb, use of modern gadgets and expert in interpretation of satellite images.

- Government should provide a satellite dedicated to military purposes that will give real time information.

- Funding of security agencies should be encouraged and a mechanism that will help to fight corruption should also be formulated to enable judicious spending of the money.

- The security agencies including Paramilitary and soldiers should have link to common database dedicated to security purposes of the country.

- Government should ensure that satellite imageries which are dedicated for security use are made available through purchase from countries that have such imageries.

- Creation of national Geospatial intelligence agency or unit in the military for effective coordination in Nigeria military.

- All military schools should be offering courses related to surveying and Geoinformatics.

\section{References}

[1]. Adebakin, M .A, (2012).National Security Challenges and Sustainable Economic Development: Evidences from Nigeria, Journal of Studies in Social Sciences, vol. 1, 1, (pp. 1-30)

[2]. Anyadike N.O, BoKo Haram ad National Security Challenges in Nigeria; Causes and Solutions, Journals of Economics and Sustainable Development, vol. 4, 5, 2013, 12-23

[3]. Boer,M. (2012): MEND: the nature of an insurgency E-international Relaton publishing retrieved $7^{\text {th }}$ May,2014 from www.eir.inro/2012/05/11mend.

[4]. Dyke V.V, Security and Sovereignty in International Politics, New York: Appleton- Century-Crofts

[5]. Fatowa,U (2012): The nature and dynamics of insurgencies, retrieved on $7^{\text {th }}$ May, 2014 from www.thenationoline.net.

[6]. Johnson, T. (2011) .Boko Haram-council on foreign relation Retrieved on $7^{\text {th }}$ May, 2004 from www.cfr.org/african/bokoharam/p25739

[7]. Mark, D. (2001). Boko Haram :Nigeria's Terror Insurgency Evolves, think Africa Press retrieved on $7^{\text {th }}$ May, 2004 from www.m.thinkaprica press .com

[8]. Microsoft Encarta premium, 2009

[9]. National System for Geospatial Intelligence, Basic Doctrine, 2006

[10]. Noam L, (1999).Fundamentals of remote sensing. London: MC HILL (pp. 34-45)

[11]. OluwaseunBamidele, Boko Haram Catastrophic Terrorism-An Albatross to National Peace, Security and Sustainable Development in Nigeria, Journal of sustainable development in Africa, Vol. 14, N0. 1, 2012, 33-44

[12]. Qihao W, (2010). Remote sensing and GIS Integration, theories, methods, and applications London: MC HILL (pp.43-49)

[13]. Robert W K, (2005).What is Sustainable Development? Goals, Indicators, Values and Practice, Environment: Sciences and Policy of Sustainable Development, vol. 47, 3, (pp. 8- 21)

[14]. Sam C .S John A.W, Stephen J.C,(2008). US National Security: Policymakers, Process and Politics $4^{\text {th }}$ ed. (USA: Lynne Rienner, 2008)

[15]. The Advent of the National Geospatial Intelligence Agency office of the NGA Historian, September, 2011

[16]. Tunde, A. (2007): History of Terrorism and Kidnapping in Nigeria Retrieved on $7^{\text {th }}$ May, 2014 from www.wordissue360.com.

[17]. Wolf,P. \&Ghilani, U. (2006). Elementary surveying: An introduction to Geomatics, upper saddle rover, new Jessy

[18]. www.bbc.com/news/world-africa

[19]. www.defenceiq.com/defence-technology/articles

[20]. www.geospatialdefense.com/lframe

[21]. www.digitalglobeblog.com/geobigdatasochi

[22]. www.wikipedia.org/geospatialintelligence

[23]. www.wikipedia.org/nationalsecurity

[24]. www.stratrisks.com/geostrat 